\title{
The social construction of sexual violence for female politicians
}

\author{
Konstruksi sosial kekerasan seksual bagi politisi perempuan
}

\author{
Tri Vena Putri ${ }^{\bowtie}$ \& Bagong Suyanto \\ Department of Sociology, Faculty of Social and Political Sciences, Universitas Airlangga \\ Surabaya, 60286, East Java Province, Indonesia \\ E-mail of corresponding author: tri.vena.putri-2020@fisip.unair.ac.id
}

\begin{abstract}
The phenomenon of sexual violence is illustrated as the iceberg phenomenon. Every year the number of cases of sexual violence increases. Among the victims of sexual violence, women are the most common ones. This study aimed to examine how the social construction of sexual violence from the side of women as female politicians. The research method was qualitative. Primary data were obtained through observation and in-depth interviews. The theory employed was the social construction theory by Peter L. Berger and Thomas Luckmann. The results showed that in the externalization process, sexual violence is a reality that still has weaknesses in its handling in Indonesia due to the existence of patriarchal values in society. The objectification process resulted in a debate between the use of the KUHP and the Elimination of Sexual Violence Bill (RUU PKS) as the legal basis for sexual violence. The internalization process is a reinterpretation of sexual violence after externalization and objectivation. This study concludes, in this process, female politicians interpret sexual violence as an act of attacking the sexuality of the victim which damages the physical and psychological aspects.
\end{abstract}

Keywords: female victims of sexual violence; sexual violence; social construction; women politicians

\begin{abstract}
Abstrak
Fenomena kekerasan seksual ini seperti fenomena gunung es. Setiap tahunnya jumlah kasus kekerasan seksual meningkat. Di antara korban kekerasan seksual yang ada, perempuan paling sering menjadi korban. Tujuan penelitian ini adalah mengkaji bagaimana konstruksi sosial kekerasan seksual dari sisi perempuan yang berperan sebagai politisi perempuan. Metode dalam penelitian ini adalah kualitatif. Data primer diperoleh melalui observasi dan wawancara mendalam. Teori yang digunakan yaitu teori konstruksi sosial oleh Peter L Berger dan Thomas Luckmann. Hasil penelitian menunjukkan bahwa pada proses eksternalisasi, kekerasan seksual merupakan suatu realitas yang masih memiliki kelemahan dalam penanganannya di Indonesia akibat masih adanya nilai patriarki di masyarakat. Proses obyektivasi menghasilkan perdebatan antara penggunaan KUHP dengan RUU PKS sebagai landasan hukum kekerasan seksual. Proses internalisasi menghasilkan pemaknaan kembali kekerasan seksual setelah eksternalisasi dan obyektivasi. Studi ini menyimpulkan, pada proses ini, politisi perempuan memaknai kekerasan seksual sebagai tindakan menyerang seksualitas korban yang merusak aspek fisik maupun psikis.
\end{abstract}

Kata Kunci: perempuan korban kekerasan seksual; kekerasan seksual; konstruksi sosial; politisi perempuan

\section{Introduction}

Sexual violence is a phenomenon that continues to grow every year. This phenomenon is illustrated as the iceberg phenomenon, indicating that of the existing cases, only a few were reported. Women are the group with the highest incidence of sexual violence. Komnas Perempuan (2020) noted that the perpetrators of sexual violence in the public sphere had the highest number, which was mostly committed by neighbors. The data of Annual Records (CATAHU) in the latest Komnas Perempuan Press Release in 2020 noted a multiplication in the number of cases of violence against women. The increasing trend has been recorded by CATAHU since 2016 show that the numbers of cases of violence against women were $259,150,348,446,406,178$, and 431,471 cases in 2016 to 2019 , respectively. The data shows that there is an increase in the number of cases of violence against women every year. However, the number of reported cases does not equal the actual cases or many cases out there remain unreported. The number of cases of violence against women has increased significantly in the past twelve years as much as $792 \%$ or almost $800 \%$, which is almost eight times. It should be noted that the data recorded is similar to the iceberg phenomenon, indicating that in actual situations, women still experience unsafe living conditions. 
One in every five women has been subjected to physical and sexual violence (Nurmawati \& Sundary 2014). In patriarchal societies, women are frequently discriminated against in their everyday lives. In the patriarchal system, men occupy a superior position such as working in the public domain, while women occupy an inferior position or work in the domestic sector, making women are considered powerless parties (Djannah 2007). Women are in a subordinated or second position, which means that men are higher in position, role, and function. Thereby, women are considered weak or second only to men (Syafe'i 2015). Consequently, women continue to face discrimination, harassment, and exploitation as a result of their status as a marginalized group. Furthermore, violence against women is gender-based, which will ultimately cause physical, sexual, or psychological harm or suffering including threats, coercion, and arbitrary denial of liberty, whether occurring in public or private life (Guamarawati 2009).

Women's violence can take various forms. In society, although acts of violence against women are increasingly widespread, few people want to understand this issue. Violence against women can be in the form of physical torture, coercion through sexual actions, and other adverse treatments (Population Report 2019). According to the United Nations (UN), violence against women is defined as an act based on gender differences that result in torture or subjecting women to physical, sexual, psychological, or other forms of threats, deprivation, or arbitrary treatment of their freedom. Violence against women can take place in both public and private spaces (Syufri 2009). Martha (2013) added, besides having an impact on sexual, physical, and psychological aspects, sexual violence against women also affects the economic aspect since individuals are coerced into performing sexual behaviors in acts of violence or sexual harassment against women.

Brownmiller (2013) in his book entitled Against Our Will: Men, Women, and Rape state that when women are subjected to violence, they prefer to remain silent and do not report it. Stereotypes against female victims of sexual violence make them feel ashamed and end up blaming themselves. When women are subjected to sexual violence in the context of a patriarchal society, they are reluctant to speak up. Sexual violence, on the other hand, can happen at any time, anywhere, and by anyone. Victims of sexual violence, especially women, bear the moral burden due to acts of sexual violence by perpetrators. For this reason, the state must be available to victims of sexual violence, as well as give a sense of security and protection for all of its citizens because the incidence of alleged violence can occur at any moment and to anybody. Gender justice is still being advocated for, and it is currently mentioned as one of the Sustainable Development Goals (SDGs) number 5, which includes the promotion of women's empowerment and gender justice (Moyo \& Dhliwayo 2019). Moreover, women as the victims of sexual violence are frequently blamed for the violence they have experienced.

Lonsway et al. (2008) show that men even blame women for being harassed and support other negative views of female victims. This is due to patriarchal beliefs in society, which prevent women who have been victims of sexual violence from receiving their right to justice as victims. Another study has found that a lack of support for victims of sexual violence is related to the perception in society about male perpetrators that "good men" do not rape (Martinez et al. 2018). What can cause female victims of sexual violence to be blamed is the lack of empathy from men who abuse women themselves, therefore understanding the perspective of male perpetrators is crucial in comprehending why women are often blamed for the sexual violence they experienced (Bongiorno et al. 2020).

Women in politics are generally divided into two targets of discussion. First, research focuses on the role of women in many facets of politics, such as political socialization, participation, and elites. Second, the research focuses on women's studies and politics as a sub-field of political science research. As a subfield of research, feminism has its own research content (ontology), methodology, epistemology, and research objectives (axiology) (Hadiz 2004). The number of DPR members who were sworn in Jakarta on October 1, 2019, shows that women are involved in politics. A total of 575 members of the DPR consist of 458 men and 117 women. In terms of the proportion of both genders, the number of women as DPR members increase 22\% from the 2014 general election, which was only 97 (Dewi 2016). On 
November 21, 2019, President Joko Widodo announced a special presidential staff that would assist him in the next five years. Seven people were elected as special staff to the president, and three of them were millennial women, including Putri Indahsari Tanjung, Ayu Kartika Dewi, and Angkie Yudistia.

Women who play an active role in political parties or the legislature can act as political communicators, both as individuals and as representatives of political institutions or organizations. In this role, women seek more direct forms of political participation to achieve political development (Zamroni 2013). The Law of the Republic of Indonesia Number 39 of 1999 concerning Women's Rights in Article 46 reads "The general election system, political party system, system of electing members of people's representative organizations, and the system of appointing executives, judges, and civil servants must ensure that women are adequately represented". Women's representation is interpreted as the provision of equal opportunities and positions for women to carry out their roles in the executive, judicial, legislative, party, and general elections towards justice and gender equality (Dewi 2016). This study also assessed that the participation of women in politics will provide a different political atmosphere. Public perception of female politicians is contradictory because when performing their roles in politics and carrying out their policies, they do not focus on solving the issue of violence. Instead, they put forward compromise, accommodation, and peace.

The sloppy handling of cases of sexual violence makes the number of cases continue to rise every year. This is in line with the findings of the study conducted by Htun \& Jensenius (2020) that the legislation on sexual violence in the context of Latin America or Mexico is still considered unable to overcome these cases. Weak legislation has consequences for non-compliance with increasingly widespread law enforcement. In the Indonesian context, the implementation of the Domestic Violence Law, Victim Protection Law, and the Anti-Human Trafficking Law in reality still require evaluation because discrimination against women, domestic violence, and sexual harassment in the workplace are still prevalent. This demonstrates that there is still a gap between the law and its implementation in society, resulting in sluggish progress toward gender equality (Suwarno 2019).

Based on these studies, the resolution of cases of sexual violence against women still has various obstacles, such as the persistence of the practice of patriarchal values in society that affects people's attitudes towards victims and the weak implementation of existing laws for handling cases of sexual violence. In the political realm, it is hoped that women's representation can be achieved well because they are considered to better understand women's interests. Therefore, women in parliament are expected to be able to convey the aspirations of women out there so that their true needs can be met (Bogie 2014).

Previous studies described the complex realities faced by female victims of sexual violence, such as stereotypes against women as victims of sexual violence, negative stigma from the surrounding community, victim-blaming behavior, feeling ashamed to report their cases to the court just because they are women and society's perceptions of sexual violence as a disgrace. Furthermore, the legislation remains ineffective in overcoming cases of sexual violence against women, making the number of cases of sexual violence continue to increase (Lonsway et al. 2008, Brownmiller 2013, Htun \& Jensenius 2020, Purwanto \& El Hariri 2020). This study aimed to examine the social construction of sexual violence for female politicians who are also representatives of the community who fight for justice for the survivors. This research provides novelty, especially on aspects of the social construction of sexual violence. The female politicians are members of the East Java DPRD in Surabaya City, specializing in gender issues and violence against women, who are also gender activists. Therefore, these female politicians have a social experience in handling cases of sexual violence and the subjective meaning of sexual violence. Therefore, it motivates the researchers to understand the social construction of sexual violence among female politicians in Surabaya.

\section{Research Method}

This research on the social construction of sexual violence for female politics employed the qualitative method. This method is used to obtain in-depth data. The reinterpretation of the results of the social 
construction of sexual violence between individuals differs depending on their social experience and subjectivity. This study focused on the female politicians who are members of the East Java DPRD and active gender activists in Surabaya City. Members of the East Java DPRD were chosen as informants because they have experience dealing with issues of violence against women, particularly sexual violence that occurred in Surabaya City. Moreover, these politicians are also activists from gender organizations that have previously engaged in a variety of activities related to the values of justice and gender equality.

The data collected consisted of primary and secondary data. This study obtained primary data through in-depth interviews with informants regarding the social construction of sexual violence. Besides, primary data was also obtained from observations on activities done by the informants in gender-based organizations that they participated in and other activities aimed to address violence against women. The secondary data were obtained through various related literature, websites of the organizations in which female politicians participate, various journal articles on violence, and news obtained via the internet to track the development of cases of violence in Indonesia as supporting data.

Determination of the informants or subjects interviewed was carried out according to the criteria in the study, including female politicians in Surabaya where cases of sexual violence against women increased year by year. However, not any female politicians were included in this study; it limits the criteria to those who have competence in gender issues, especially in the field of women's problems, such as sexual violence. Following the establishment of the criteria, this study involved five female political informants who were members of the East Java DPRD, including LES, AGA, HAB, EMA, and HIK. Non-subject informants were also needed in this study to validate the data collected as well as to add variety and depth to the data. The non-subject informants of this study included the head of Koalisi Perempuan Indonesia (KPI) of East Java, the head of the NGO Savy Amira Women's Crisis Centre, two female victims of sexual violence who have reported to the KPI of East Java, and Savy Amira and whose cases have been handled by the informants.

Table 1.

List of Informants

\begin{tabular}{|c|c|c|c|c|}
\hline No. & Name & Occupation & Age (year) & Position as activists \\
\hline 1 & LES & $\begin{array}{l}\text { Member of the East Java DPRD } \\
\text { Commission E }\end{array}$ & 56 & $\begin{array}{l}\text { KPI of East Java member, } \\
\text { legal assistant }\end{array}$ \\
\hline 2 & HAB & $\begin{array}{l}\text { Member of the East Java DPRD } \\
\text { Commission E }\end{array}$ & 50 & $\begin{array}{l}\text { Savy Amira member, women, } \\
\text { and children observer }\end{array}$ \\
\hline 3 & AGA & $\begin{array}{l}\text { Member of the East Java DPRD } \\
\text { Commission B }\end{array}$ & 47 & $\begin{array}{l}\text { KPI of East Java member, } \\
\text { legal assistant }\end{array}$ \\
\hline 4 & EMA & $\begin{array}{l}\text { Member of the East Java DPRD } \\
\text { Commission E }\end{array}$ & 52 & $\begin{array}{l}\mathrm{KPI} \text { of East Java member, } \\
\text { legal assistant }\end{array}$ \\
\hline 5 & HIK & $\begin{array}{l}\text { Member of the East Java DPRD } \\
\text { Commission E }\end{array}$ & 43 & $\begin{array}{l}\text { Savy Amira member, women, } \\
\text { and children observer }\end{array}$ \\
\hline 6 & SIT & Head of Savy Amira WCC & 50 & Psychology Lecturer \\
\hline 7 & WIW & $\begin{array}{l}\text { Deputy Head of KPI of East } \\
\text { Java }\end{array}$ & 42 & $\begin{array}{l}\text { Head of the department of } \\
\text { undergraduate program of } \\
\text { law }\end{array}$ \\
\hline 8 & RIT & Sexual violence survivor & 17 & Student \\
\hline 9 & ALI & Sexual violence survivor & 35 & Housewife \\
\hline
\end{tabular}

Table 1 shows the data of the informants who helped the researchers in collecting primary data through indepth interviews. Various perspectives are required in qualitative research apart from subject informants because the depth of data serves as a priority in obtaining data rather than the number of informants. After conducting in-depth interviews, the researchers then conducted data analysis. The researchers categorize data based on the research results according to the qualitative method used. Data grouping 
or categorization is a qualitative data processing method based on points that are linear to the research focus (Suyanto \& Sutinah 2007). The method of data analysis begins with data collection at the research location, either in the form of observation or interviews. The data is subsequently condensed, presented, categorized, and a conclusion is reached (Miles et al. 2014). The qualitative data analysis was carried out by first transcribing the results of the interviews, then categorizing the data, and finally analyzing the data using the theory as an analytical tool.

\section{Results and Discussion}

\section{Sexual violence: Definition and subjective meaning}

According to Berger \& Luckmann (1990), there are three forms of social reality. The first is an objective social reality, which can be demonstrated through a normative definition of sexual violence. Sexual violence is defined as behavior that tends to lead to sexual solicitation, such as touching, fingering, kissing, and/or performing other behaviors that are not desired by the victims, forcing the victim to consume pornographic content, joking with sexual intent, insulting and harassing, mentioning aspects of gender, victimizing others and forcing them to have sex without their consent, and having sex because of coercion (Anisa \& Santoso 2020). The second reality is subjective or symbolic reality, which is considering that acts of sexual violence can indeed occur to men and women, but based on the studies conducted by Gravelin et al. (2019) and Oktaviani \& Azeharie (2020), sexual violence is mostly experienced by women compared to men. The third is subjective social reality or a combination of the two previous forms of reality, objective reality, and subjective reality. In this third form of reality, there is a polemic regarding the ratification of the Elimination of Sexual Violence Bill. This polemic began with an idea from Komnas Perempuan regarding the urgency of drafting the Draft Law on the Elimination of Sexual Violence since 2014 aiming at upholding justice for survivors of sexual violence (Komnas Perempuan 2020). Despite having authority, DPR has not included the Elimination of Sexual Violence Bill in the priorities of the National Legislation Program (Prolegnas) in 2020 due to the pro and contra caused by the Elimination of Sexual Violence Bill. The decision to eradicate the Elimination of Sexual Violence Bill from the 2020 Priority Prolegnas is still being considered. The reason for this is that the Commission VIII of the House of Representatives of the Republic of Indonesia has raised the issue. Commission VII cited the need for the Indonesian House of Representatives to focus on finalizing the Elderly Bill and the Disaster Bill as the reason for the temporary suspension of further discussion of the Sexual Violence Bill (CNN Indonesia 2020)

Based on Komnas Perempuan's Annual Records (CATAHU) (2020), the number of cases of violence against women in 2019 in Indonesia was 431,479. This represents a 6\% increase over the previous year when 406,178 cases were reported. In the case of sexual violence against women, recorded data reveals a drop in the number of cases from 5,280 in 2018 to 4,898 in 2019. The number of recorded cases, however, does not represent the actual situation. It should be noted that the phenomenon of sexual violence is like an iceberg phenomenon, with reported occurrences of sexual violence differing from actual cases on the ground.

Female politicians define sexual violence based on their subjective understanding. Acts of sexual violence, according to the informants LES, HAB, EMA, and AGA, are acts that target the sexuality of others without consent and cause harm to the physical and psychological aspects of the victims (Biruny et al. 2015).

"Actions that attack other people's sexuality are certainly not only about sexual organs but also gender identity, sexual function, how to dress, which clearly robs one's sexual rights, robs one's right to expression, including one's sexual attraction, forced contraception, and forced marriage. Sexual violence can have both physical and psychological consequences. The impacts are complex." (The informant HAB) 
Based on the statement of the informant HAB, sexual violence is not only defined normatively but has a complex meaning. The informant HAB also defined sexual violence based on her subjectivity, which results from her social experience and knowledge possessed. Sexual violence can cause a variety of health issues for its victims, such as physical trauma or injury, unplanned pregnancy, intentional abortion, gynecological problems, and Sexually Transmitted Infections (STIs) including HIV. If a pregnant woman is subjected to sexual violence, her chances of miscarriage, stillbirth, premature delivery and low birth weight are elevated (LBW). Furthermore, according to the Elimination of Sexual Violence Bill of the Republic of Indonesia, this violent behavior can also lead to psychiatric illnesses, including depression, post-traumatic stress disorder (PTSD) and other anxiety disorders, sleep disorders, eating disorders, and suicide attempts.

\section{The use of the Criminal Code (KUHP) and the discourse on the Elimination of Sexual Violence Bill}

Every citizen has guaranteed the right to obtain a sense of freedom and security against all types of violence in the 1945 Constitution of the Republic of Indonesia and the Pancasila philosophy. (Muhajarah 2016). In Indonesia, acts of sexual violence have been regulated in laws and regulations, particularly in the Criminal Code (KUHP). Perpetrators of sexual violence have been sentenced to criminal penalties. Issues in dealing with acts of sexual violence, however, are still tied to Indonesian laws and regulations, such as sexual violence, which is still regulated independently under this law. This indicates that no law has specifically regulated sexual violence (Rais et al. 2019).

Sexual violence legislation and execution in every country differs in terms of how it is applied and the challenges it faces, based on the country's system and society. Between 2014 and 2017, the several Islamic States that controlled crucial areas in Iraq and Syria engaged in various forms of violence against civilians living in these areas. A study revealed that these Islamic States are a country near ISIS-controlled territory. The study was conducted by employing interviews with Syrian and Iraqi citizens who have knowledge of organizational policies including victims of the violence and former ISIS combatants. In the states in the are of the organization of ISIS, there are violations of policies that cause sexual violence to occur. The results of this study discovered evidence of sexual violence in two forms, including gang-rape against Yazidi women and forced marriages against Sunni Muslim women (Revkin \& Wood 2021). In the United States and the United Kingdom, policies on sexual violence are also being discussed. A study discussed student activism movements in the United States and the United Kingdom about sexual violence policies on campus. Both countries were chosen for comparison because they share a demographic environment that is similar in many respects. Collaboration between student activists and institutions could be a good step forward in terms of community consideration of responsibility for sexual violence prevention (Bovill et al. 2021).

"The use of existing laws such as the existing law on child protection and domestic violence is possible, but socialization is still lacking, including in the media such as television, radio, social media, government media or through village heads, community leaders, religious leaders. I think the socialization is still lacking." (The informant LES)

Meanwhile, efforts to overcome current sexual violence can be carried out by optimizing the application of the Criminal Code as the legal basis for acts of sexual violence. The informant LES, who is a member of the DPRD of East Java on Commission E and a legal assistant at the Indonesian Women's Coalition in East Java, emphasized that the absence of socialization on penalty for sexual violence perpetrators resulted in unsatisfactory regulation implementation. In addition to being the government's responsibility, sexual violence can also be prevented by the community, which is by providing protection to victims, preventing potential perpetrators, and providing emergency assistance (Juita 2018).

Eventually, the discourse on the Elimination of Sexual Violence Bill (RUU PKS) emerged. This bill was initiated in 2012. The Elimination of Sexual Violence Bill was proposed as a breakthrough for a newly legal product in order to eliminate all forms of sexual violence. This is due to the fact that many women who have been victims of sexual violence continue to be denied justice. Sexual violence accounts for around a quarter of all recorded occurrences of violence against women (Komnas Perempuan 2017). 
The informants AGA, HAB, EMA, HIK, and LES as female politicians and gender activists keep assisting the process so that the Elimination of Sexual Violence Bill is immediately passed. The draft that has been filed may be a response to the need of victims who have not received adequate compensation for the sexual violence they have experienced.

"The Elimination of Sexual Violence Bill was initiated so that later when a victim reports it will be considered a criminal case. For example, a catcalling case is not considered an unpleasant act in the Criminal Code. It is also difficult to prove the violence. Well, things like that are the background for the initiation of the Elimination of Sexual Violence Bill." (The informant AGA)

The Elimination of Sexual Violence Bill provides regulations for sexual violence in order to further protect the rights of victims. Much more specific provisions related to sexual violence in the Elimination of Sexual Violence Bill can also regulate punishments that are not specified in the Criminal Code (Rais et al. 2019). The Elimination of Sexual Violence Bill for the informant AGA will eventually be able to reach out to forms of sexual violence such as catcalling which is not regulated in the Criminal Code. This is because the Elimination of Sexual Violence Bill is aimed to regulate nine types of sexual violence, including sexual harassment, sexual exploitation, forced contraception, forced abortion, rape, forced marriage, forced prostitution, sexual slavery, and sexual torture.

\section{The social construction of sexual violence for female politicians}

Reality is formed through a dialectical process experienced by each individual. Individuals form reality or reinterpret their socio-cultural world through three stages, including externalization, objectivation, and internalization, according to Berger and Luckmann. In the externalization process, individuals observe and perceive reality as an object outside of themselves, which they study and adapt to on a constant basis. This is called "society is a human product". The objectivation process is a social interaction in the intersubjective world that is institutionalized which is called "society is an objective reality". The internalization process is the re-absorption of the objective world into individual consciousness, which is called "man is a social product" (Berger \& Luckmann 1990).

The externalization process made female politicians of the DPRD of East Java as well as KPI of East Java and Savy Amira members aware of any acts of sexual violence that occurred, either through direct observation, television, radio, and internet media. Every year, the number of cases of sexual violence rises. Sexual assault against women is common, and victims' rights to justice and compensation are still unmet.

\footnotetext{
"At first I knew from the news on television related to the law on labor involving women. So they are the ones who experience sexual violence the most. I got to know some people for a long time, then I finally joined KPI." (The informant LES)
}

This study also provides statements of experiences from sexual violence survivors who have reported to the KPI of East Java or Savy Amira. It is as stated by a non-subject informant, ALI, who is a victim of Domestic Violence (KDRT).

\footnotetext{
"When I experienced domestic violence, I didn't want to immediately report it to the police. Actually, it is because I'm still not ready to be asked various questions by the police, then I finally looked around on the internet. I found an institution that is willing to accept complaints like this. In the end, I went to KPI and the people there were very welcome and willing to accompany me although KPI was not a place specifically for dealing with victims of sexual violence. There, they have a strong sisterhood atmosphere." (The informant ALI)
}

Complaints regarding acts of sexual violence were reported by the informants ALI and RIT. Both chose to report their experience to gender-based institutions or organizations. Reporting to an institution or 
organization is considered more likely to make them feel secure when compared to having to report directly to the police. Moreover, their reason is that the reporting process in the police is much more complex and some are considered not to take sides with victims of sexual violence, particularly women. Therefore, the two survivors eventually chose to report to the two organizations without feeling intimidated by some officers who did not have a gender perspective.

Sexual violence against women as victims is a socio-cultural area. This is due to the patriarchal norms of society's deficient treatment of issues, which eventually tend to blame the victims, causing female politicians to continue to face forms of adaptation to the socio-cultural area. It is one of the cases of victims of sexual violence that occurred to minors, which is included in the case of Online-Based Gender Violence (KBGO).

\begin{abstract}
"When I was in middle school, I met someone on one of my social media accounts. We do sexting and sex video call. During the video call, we did sexual things and then recorded them. But then, I was threatened that he would share the video if I didn't comply. I'm confused. Then I reported to Savy and told them everything but they said there had to be a guardian or parent. I am afraid of this situation." (The informant RIT)
\end{abstract}

The statement revealed by one of the sexual violence survivors, RIT, which experienced sexual violence at a young age, is proof that sexual violence can happen to anyone and through anything, including the internet. KBGO is one of the world's most serious societal problems, causing both direct and indirect physical and mental harm to victims. Victims of psychological harm frequently experience higher degrees of psychological distress as well as long-term effects such as depression (Illene et al. 2019). KBGO refers to a new category of sexual violence cases. As a result, the legal basis for KBGO remains unclear. The case will be handled by law enforcement personnel once the victim has reported it. The law used is UU ITE or UU no. 44 of 2008. However, the law still has weaknesses because it does not have a gender perspective (Hikmawati 2021).

The objectification process resulted in the efforts of female politicians in resolving cases of sexual violence against women. As female politicians as well as legal assistants for victims who report to the KPI of East Java and Savy Amira, the determination of punishments for perpetrators of sexual violence to date can be carried out by maximizing the use of the Criminal Code as a legitimized legal product. Optimization of the Criminal Code for solutions to sexual violence is to enhance socialization activities in the community. Eventually, there is the debate over the settlement of sexual violence cases with the initiation of the Elimination of Sexual Violence Bill which has been a discourse since 2012. This bill was proposed as a way out for the future of victims whose rights have not been fulfilled and have not received justice.

Based on a legal perspective, the Elimination of Sexual Violence Bill is considered a lex specialis or a special provision in the Criminal Code because it regulates the crime of sexual violence which is not regulated in the Criminal Code (Mahabbati \& Sari 2019). Therefore, the effort that needs to be carried out is updating the KBGO arrangement in the 2019 Criminal Code, and specifically being included in the Elimination of Sexual Violence Bill. It should be clearly stated that KBGO is a form of sexual violence (Hikmawati 2021).

The internalization process resulted in a reinterpretation of sexual violence for female politicians. Violence is defined as an act of targeting the victim's sexuality which can cause harm to both the physical and psychological aspects resulting in trauma for a lifetime. According to female politicians, women are not the cause of sexual violence. Although sexual violence can happen to anyone, many studies reveal that women are more likely to experience sexual violence than men. When women are subjected to violence, they choose to remain silent and do not report it (Brownmiller 2013).

\footnotetext{
"We once assisted the victim by assisting the victim when she reported her case to the court. As a member of the organization, I also accompanied the victims. In principle, we look at the needs of victims, whether they need legal assistance or only psychological assistance." (The informant AGA)
} 
The informant AGA who is a politician and member of the KPI of East Java as well as a legal assistant for survivors who report to KPI stated that her experience in handling cases of sexual violence required a long process to reach the court. As a legal assistant, the informant AGA assists survivors in preparing all evidence because the investigation process requires appropriate evidence. As a result, the case can be followed up on right away, and the perpetrator can be sentenced right away.

Therefore, acts of sexual violence remain the perpetrator's fault. Even when it is known that the victim is a woman, there should be no bias in the handling of sexual violence. Women who are victims of sexual violence are treated as a disgrace and a moral burden in society, and as a result, they face discrimination, harassment, and exploitation (Guamarawati 2009).

\section{Conclusion}

This study resulted in the social construction of female politicians on the phenomenon of sexual violence. The results revealed that the social construction of sexual violence for female politicians went through a dialectic process, including externalization, objectivation, and internalization. The externalization process results in a reality of the weak handling of cases of sexual violence in the community. The objectification process culminated in the optimization of the Criminal Code as a legal basis for handling sexual violence and the emergence of the discourse on the Elimination of Sexual Violence Bill. In the internalization process, female politicians subjectively define sexual violence, which is acts of sexuality carried out forcibly by perpetrators against victims that cause physical, psychological, social, and economic harm to the victims. Although many studies have been conducted on sexual violence, research on the social construction of sexual violence for female politicians has not been widely carried out. The findings of this study could lead to new knowledge in the field of social construction research, as well as for female politicians dealing with incidents of sexual violence.

\section{References}

Anisa \& Santoso MBB (2020) Penanganan kekerasan seksual terhadap perempuan dalam situasi bencana. In: Prosiding Penelitian dan Pengabdian kepada Masyarakat 7 (1):208. https://doi.org/10.24198/ jppm.v7i1.22881.

Berger PL \& Luckmann (1990) Tafsir Sosial atas Kenyataan. Jakarta: LP3ES.

Biruny DM, Rohmah N, \& Rifanda N (2015) Kekerasan seksual pada anak: Telaah relasi pelaku korban dan kerentanan pada anak. Jurnal Psikologi Islam 12 (2):5-10.

Bogie E (2014) Politisi perempuan dalam menanggapi isu gender studi kualitatif tentang isu gender dalam bidang pendidikan, ketenagakerjaan, dan kesehatan di DPRD Surabaya. Thesis, Universitas Airlangga, Surabaya.

Bongiorno R, Langbroek C, Bain PG, Ting M, \& Ryan MK (2020) Why women are blamed for being sexually harassed: The effects of empathy for female victims and male perpetrators. Psychology of Women Quarterly 44 (1):11-27. https://doi.org/10.1177/0361684319868730.

Bovill H, Mcmahon J, Demers J, Banyard V, Carrasco V, \& Keep L (2021) How does student activism drive cultural campus change in the UK and US regarding sexual violence on campus? Critical Social Policy 41 (2):165-187. https://doi.org/10.1177/0261018320913967.

Brownmiller S (2013) Against Our Will: Men, Women, and Rape (4th edn). New York: Open Road Media.

CNN Indonesia (2020) Dalih DPR cabut RUU PKS: Picu polemik di antara perempuan. CNN Indonesia, 01 July. [Accessed 19 July 2021]. https://www.cnnindonesia.com/ nasional/20200701133238-32-519508/dalih-dpr-cabut-ruu-pks-picu-polemik-di-antaraperempuan.

Dewi H (2016) Perempuan dan pollitik dalam perspektif kesetaraan gender. [Accessed 19 July 2021]. https://sumbarprov.go.id/home/news/8277-perempuan-dan-politik-dalam-perspektif-kesetaraangender. 
Djannah F (2007) Kekerasan Terhadap Istri. Yogyakarta: LKiS.

Gravelin CR, Biernat M, \& Bucher CE (2019) Blaming the victim of acquaintance rape: Individual, situational, and sociocultural factors. Frontiers in Psychology 9 (2422):1-22. https://doi. org/10.3389/fpsyg.2018.02422.

Guamarawati NA (2009) Suatu kajian kriminologis mengenai kekerasan terhadap perempuan dalam relasi pacaran heteroseksual. Jurnal Kriminologi Indonesia 5 (1):43-55.

Hadiz L (2004) Perempuan dalam Wacana Politik Orde Baru. Jakarta: Pustaka LP3ES Indonesia.

Hikmawati P (2021) Pengaturan kekerasan berbasis gender online: Perspektif ius constitutum dan ius constituendum. Negara Hukum 12 (1):59-79. https://doi.org/10.22212/jnh.v12i1.2124.

Htun M \& Jensenius FR (2020) Aspirational laws as weak institutions: Legislation to combat violence against women in Mexico. The Politics of Institutional Weakness in Latin America 1:141-160. https://www.cambridge.org/core/books/politics-of-institutional-weakness-in-latin-america/ aspirational-laws-as-weak-institutions/604364DD3C56F05CFCEC29EB1FFB2AD7.

Illene A, Damajanti MN, \& Muljosumarto C (2019) Perancangan kampanye sosial mengenai kekerasan gender berbasis online. Jurnal DKV Adiwarna, Universitas Kristen Petra 1 (14):1-10.

Juita S (2018) Peran serta masyarakat dalam upaya pencegahan kekerasan terhadap anak dari perspektif hukum pidana. Jurnal Penelitian Pendidikan Sosial Humaniora 3 (1):355-362. https://doi. org/10.32696/jp2sh.v3i1.99.

Komnas Perempuan (2017) Naskah Akademik Rancangan Undang-Undang Tentang Penghapusan Kekerasan Seksual. Jakarta: Komnas Perempuan.

Komnas Perempuan (2020) Catatan Tahunan (CATAHU): Kebijakan penghapusan kekerasan seksual untuk membangun ruang aman bagi perempuan dan anak perempuan. [Accessed 15 February 2021]. http://komnasperempuan.go.id/file/pdf_file/2020/Catatan Tahunan Kekerasan Terhadap Perempuan 2020.pdf.

Lonsway K, Cortina L, \& Magley VJ (2008) Sexual harassment mythology: Definition, conceptualization, and measurement. Sex Roles 58:599-615. https://doi.org/10.1007/s11199-007-9367-1.

Martha AE (2013) Perempuan, Kekerasan dan Hukum. Yogyakarta: UII Press.

Martinez T, Wiersma-Mosley, Jozkowski J, \& Becnel J (2018) "Good guys don't rape": Greek and non-Greek college student perpetrator rape myths. Behavioral Sciences 8:1-10. https://doi. org $/ 10.3390 / \mathrm{bs} 8070060$.

Miles MB, Huberman AM, \& Saldana J (2014) Qualitative Data Analysis: A Methods Sourcebook. London: Sage Publications.

Muhajarah K (2016) Kekerasan terhadap perempuan dalam rumah tangga: Perspektif sosio-budaya, hukum, dan agama. Sawwa: Jurnal Studi Gender 11 (2):127-146. https://dx.doi.org/10.21580/ sa.v11i2.1452.

Moyo T \& Dhliwayo R (2019) Achieving gender equality and women's empowerment in Sub-Saharan Africa: Lessons from the experience of selected countries. Journal of Developing Societies 35 (2):256-281. https://doi.org/10.1177/0169796X19845957.

Nurmawati \& Sundary A (2014) Modul Diskusi Komunitas untuk Remaja Perempuan (Program LakiLaki Peduli). Yogyakarta: Rifka Annisa Women's Crisis Center.

Oktaviani R \& Azeharie SS (2020) Penyingkapan diri perempuan penyintas kekerasan seksual. Koneksi $4(1): 98-105$.

Population Report (n.d.) Ending Violence Against Woman.

Purwanto P \& el Hariri DB (2020) Social construction of husband of female migrant workers on children's education. Jurnal Sosiologi Dialektika 15 (1):1-8.

Rais NF, Manurung GP, \& Wardani AK (2019) Analisis keberlakuan RKUHP dan RUU-PKS dalam mengatur tindak kekerasan seksual. Lex Scientia Law Review 3 (1):55-68.

Revkin M \& Wood E (2021) The Islamic state's pattern of sexual violence: ideology and institutions, policies and practices. Journal of Global Security Studies 6 (2):1-20. https://doi.org/10.1093/ jogss/ogaa038.

Suwarno P (2019) Equality in education and employment for sustainable development of diverse Indonesia: Enhancing equal opportunity, volunteerism, and philanthropy. Non Formal Education International Conference (NFEIC 2018) 293:1-8. https://doi.org/10.2991/nfeic-18.2019.1. 
Putri \& Suyanto: "The social construction of sexual violence for female politicians"

Suyanto B \& Sutinah (2007) Metode Penelitian Sosial Berbagai Alternatif Pendekatan. Jakarta: Prenadamedia Group.

Syafe'i I (2015) Subordinasi perempuan dan implikasinya terhadap rumah tangga. Analisis: Jurnal Studi Keislaman 15 (1):143-166.

Syufri (2009) Perspektif sosiologis tentang kekerasan terhadap perempuan dalam rumah tangga. Jurnal Academica 1:95-105.

Zamroni M (2013) Perempuan dalam kajian komunikasi politik dan gender. Jurnal Dakwah 14 (1):103132. 